\title{
REAL-TIME SYSTEMS IN MECHATRONIC APPLICATIONS
}

edited by

\author{
Jan Wikander \\ Royal Institute of Technology
}

Bertil Svensson

Chalmers University of Technology

and

Halmstad University

\author{
A Special Issue of \\ REAL-TIME SYSTEMS
}

The International Journal of Time-Critical Computing Systems

Volume 14, No. 3 (1998)

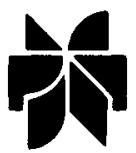

KLUWER ACADEMIC PUBLISHERS

Boston / Dordrecht / London 


\title{
REAL-TIME SYSTEMS
}

\section{The International Journal of Time-Critical Computing Systems}

\author{
Volume 14, No. 3, May 1998
} Special Issue on Real-Time Systems in Mechatronic Applications
Guest Editors: Jan Wikander and Bertil Svensson

Editorial Jan Wikander and Bertil Svensson 1

Fundamentals of Implementing Real-Time Control Applications in Distributed Computer Systems .......................... Martin Törngren

Design and Programming Tools for Time Critical Applications ............ ......... Paolo Ancilotti, Giorgio Buttazzo, Marco Di Natale and Marco Spuri

Rapid Prototyping of Real-Time Information Processing Units for Mechatronic Systems ..................... Hans-Juergen Herpel and M. Glesner

Implementation of Hard Real-Time Embedded Control Systems ............ ........ Matjaž Colnarič, Domen Verber, Roman Gumzej and Wolfgang A. Halang

HEDRA: Heterogeneous Distributed Real-Time Architecture ............. \begin{tabular}{lr}
$\ldots \ldots \ldots \ldots \ldots \ldots \ldots \ldots \ldots$ \\
\hline Open Embedded Control . . . . . . Klas Nilsson, Anders Blomdell and Olof Laurin & 109
\end{tabular} Open Embedded Control ......... Klas Nilsson, Anders Blomdell and Olof Laurin 109

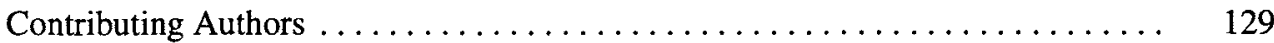


Distributors for North, Central and South America:

Kluwer Academic Publishers

101 Philip Drive

Assinippi Park

Norwell, Massachusetts 02061 USA

Distributors for all other countries:

Kluwer Academic Publishers Group

Distribution Centre

Post Office Box 322

3300 AH Dordrecht, THE NETHERLANDS

\section{Library of Congress Cataloging-in-Publication Data}

A C.I.P. Catalogue record for this book is available from the Library of Congress.

Copyright $\odot 1998$ by Kluwer Academic Publishers

All rights reserved. No part of this publication may be reproduced, stored in a retrieval system or transmitted in any form or by any means, mechanical, photocopying, recording, or otherwise, without the prior written permission of the publisher, Kluwer Academic Publishers, 101 Philip Drive, Assinippi Park, Norwell, Massachusetts 02061

Printed on acid-free paper.

Printed in the United States of America 